University of Nebraska - Lincoln

DigitalCommons@University of Nebraska - Lincoln

USDA Wildlife Services - Staff Publications

U.S. Department of Agriculture: Animal and Plant Health Inspection Service

2011

Evaluation of Fences for Containing Feral Swine under Simulated Depopulation Conditions

\author{
Michael J. Lavelle \\ USDA/APHIS/WS National Wildlife Research Center, michael.j.lavelle@aphis.usda.gov \\ Kurt C. Vercauteren \\ USDA-APHIS-Wildlife Services, kurt.c.vercauteren@usda.gov \\ Hefley \\ University of Nebraska-Lincoln, trevorhefley@msn.com \\ Gregory E. Phillips \\ USDA-APHIS, Wildlife Services \\ Scott Hygnstrom \\ University of Nebraska-Lincoln, shygnstrom1@unl.edu
}

See next page for additional authors

Follow this and additional works at: https://digitalcommons.unl.edu/icwdm_usdanwrc

Part of the Life Sciences Commons

Lavelle, Michael J.; Vercauteren, Kurt C.; Hefley; Phillips, Gregory E.; Hygnstrom, Scott; Long, David B.; Fischer, Justin W.; Swafford, Seth R.; and Campbell, Tyler A., "Evaluation of Fences for Containing Feral Swine under Simulated Depopulation Conditions" (2011). USDA Wildlife Services - Staff Publications. 1326.

https://digitalcommons.unl.edu/icwdm_usdanwrc/1326

This Article is brought to you for free and open access by the U.S. Department of Agriculture: Animal and Plant Health Inspection Service at DigitalCommons@University of Nebraska - Lincoln. It has been accepted for inclusion in USDA Wildlife Services - Staff Publications by an authorized administrator of DigitalCommons@University of Nebraska - Lincoln. 


\section{Authors}

Michael J. Lavelle, Kurt C. Vercauteren, Hefley, Gregory E. Phillips, Scott Hygnstrom, David B. Long, Justin W. Fischer, Seth R. Swafford, and Tyler A. Campbell 


\title{
Evaluation of Fences for Containing Feral Swine under Simulated Depopulation Conditions
}

MICHAEL J. LAVELLE, United States Department of Agriculture, Animal and Plant Health Inspection Service, Wildife Services, National Wildlife Research Center, Fort Collins, CO 80521-2154, USA

KURT C. VERCAUTEREN, ${ }^{\mathbf{1}}$ United States Department of Agriculture, Animal and Plant Health Inspection Service, Wildlife Services, National Wildlife Research Center, Fort Collins, CO 80521-2154, USA

TREVOR J. HEFLEY, University of Nebraska, School of Natural Resources, Lincoln, NE 68583-0974, USA

GREGORY E. PHILLIPS, United States Department of Agriculture, Animal and Plant Health Inspection Service, Wildlife Services, National Wildlife Research Center, Fort Collins, CO 80521-2154, USA

SCOTT E. HYGNSTROM, University of Nebraska, School of Natural Resources, Lincoln, NE 68583-0974, USA

DAVID B. LONG, United States Department of Agriculture, Animal and Plant Health Inspection Service, Wildife Services, National Wildlife Research Center, Texas Field Station, Kingsville, TX 78363, USA

JUSTIN W. FISCHER, United States Department of Agriculture, Animal and Plant Health Inspection Service, Wildlife Services, National Wildlife Research Center, Fort Collins, CO 80521-2154, USA

SETH R. SWAFFORD, United States Department of Agriculture, Animal and Plant Health Inspection Service, Wildlife Services, Columbia, MO 65202, USA

TYLER A. CAMPBELL, United States Department of Agriculture, Animal and Plant Health Inspection Service, Wildlife Services, National Wildlife Research Center, Texas Field Station, Kingsville, TX 78363, USA

\begin{abstract}
Populations of feral swine (Sus scrofa) are estimated to include $>2$ million animals in the state of Texas, USA, alone. Feral swine damage to property, crops, and livestock exceeds $\$ 50$ million annually. These figures do not include the increased risks and costs associated with the potential for feral swine to spread disease to domestic livestock. Thus, effective bio-security measures will be needed to quickly isolate affected feral swine populations during disease outbreaks. We evaluated enclosures built of $0.86-\mathrm{m}$-tall traditional hog panels for containing feral swine during 35 trials, each involving 6 recently caught animals exposed to increasing levels of motivation. During trials, fences were $97 \%$ successful when enclosures were entered by humans for maintenance purposes; $83 \%$ effective when pursued by walking humans discharging paintball projectors; and in limited testing, $100 \%$ successful when pursued and removed by gunners in a helicopter. In addition to being effective in containing feral swine, enclosures constructed of hog panels required simple hand tools, took $<5 \mathrm{~min} / \mathrm{m}$ to erect, and were inexpensive ( $\$ 5.73 / \mathrm{m}$ excluding labor) relative to other fencing options. As such, hog-panel fences are suitable for use by state and federal agencies for rapid deployment in disease response situations, but also exhibit utility for general control of other types of damage associated with feral swine. (c) 2011 The Wildlife Society.
\end{abstract}

KEY WORDS classical swine fever, containment, disease, fence, feral swine, foot-and-mouth disease, pig, Sus scrofa, Texas, wildlife damage management.

Feral swine (Sus scrofa) are considered an invasive pest species in many areas and continue to expand their range across the United States (Ditchkoff and West 2007). Damage-associated impacts resulting from feral swine include, but are not limited to, degradation of native vegetation (Cushman et al. 2004, Campbell and Long 2009), predation on wildlife and livestock (Plant 1980, Seward et al. 2004), and transmission of disease to humans (Atwill et al. 1997, Jay et al. 2007,

Received: 4 March 2010; Accepted: 27 October 2010;

Published: 25 May 2011

${ }^{1}$ E-mail: kurt.c.vercauteren@aphis.usda.gov
Wilcox and Van Vuren 2009) and livestock (Romero et al. 2001, Meng et al. 2009, Swafford et al. 2009, Wyckoff et al. 2009). The increased abundance and range of feral swine combined with their susceptibility and potential to transmit a variety of endemic as well as foreign animal and zoonotic diseases constitutes a national bio-security risk for agriculture.

Feral swine are susceptible to many diseases that are transmissible to cattle (e.g., foot-and-mouth disease [FMD], bovine tuberculosis, brucellosis; Meng et al. 2009) and domestic swine (e.g., classical swine fever [CSF], Brugh et al. 1964; African swine fever, McVicar et al. 1981, Meng et al. 2009; pseudorabies, Romero et al. 2001, 
Wyckoff et al. 2009). Feral swine can act as a reservoir for FMD (Thomson et al. 2003, Cowled and Garner 2008) and CSF (Laddomada 2000, Kramer-Schadt et al. 2007), creating a persistent threat to livestock production. When outbreaks have occurred in wildlife, culling has been the preferred technique to control the diseases (Artois et al. 2001, 2002; Pineda-Krch et al. 2010).

Cattle and domestic swine in the United States account for nearly $\$ 100$ billion in inventory ( $\$ 95$ billion and $\$ 4.7$ billion, respectively; US Census Bureau 2009). An outbreak of FMD in the United Kingdom in 2001 resulted in estimated losses $>\$ 10$ billion (Thompson et al. 2002). Economic losses, potentially exceeding $\$ 4$ billion, would be likely if outbreaks of FMD or CSF occurred in the United States (Paarlberg et al. 2009, Pineda-Krch et al. 2010). For example, the OIE (World Organization for Animal Health) makes no distinction between FMD infections in wildlife and domestic livestock when determining diseasefree status of a country and disease-free countries typically restrict trade from countries where disease occurs (Thomson et al. 2003, Rossi et al. 2005, World Organization for Animal Health, 2009). As such, an outbreak of an acute, highly contagious disease such as FMD or CSF involving feral swine in the United States could result in an economic catastrophe to the livestock industry (Dudley and Woodford 2002, Thomson et al. 2003, Ward et al. 2009a,b).

The use of common livestock fences (e.g., woven-wire mesh, electric polyrope) to restrict movements of feral swine can be challenging because animals can root under or escape through fences (Hone and Atkinson 1983). As such, researchers recommend 0.80-1.2-m-tall woven-wire mesh fence with an additional ground-level strand of barbed wire to create a swine-proof fence (Hone and Atkinson 1983, Hone and Stone 1989, Anderson and Stone 1993, Katahira et al. 1993, Doupé et al. 2009). An 0.8-m-tall wire-mesh fence $(>75 \mathrm{~km})$ effectively controlled movements of feral swine, facilitating eradication of feral swine from several management units in Hawaii Volcanoes National Park (Hone and Stone 1989). A fence in California totaling $42 \mathrm{~km}$ and costing $\$ 2$ million enabled land managers in the Pinnacles National Monument to successfully eradicate feral swine from $57 \mathrm{~km}^{2}$ (McCann and Garcelon 2008). Electric fences can also be effective in decreasing movements of feral swine (Hone and Atkinson 1983, Reidy et al. 2008, Vidrih and Trdan 2008). Published research on fences for feral swine primarily has evaluated fences under essentially natural levels of motivation without incorporating humaninduced provocation, which provided valuable information limited to situations such as excluding feral swine from agricultural crops. However, as on-the-ground human activity increases, feral swine often respond by dispersing, demonstrating an increase in motivation to escape potential danger (Richardson et al. 1997, Sodeikat and Pohlmeyer 2003, Geisser and Reyer 2004).

Efficacy of a fence for preventing passage by ungulates reflects the level of motivation of individual animals (VerCauteren et al. 2006a). We sought to evaluate how effective a fence could be in containing feral swine once depopulation activities began and levels of motivation increased. In the event of a disease outbreak in feral swine, containing them in a quickly erected fence followed by lethal removal would be a strategy for preventing feral swine from spreading disease, but an appropriate fence needs to be determined for containing feral swine under human-induced levels of motivation to escape.

Our objectives were to 1) conduct a pilot study of 5 fence types suggested as having potential for containing feral swine, 2) evaluate behavioral responses of feral swine to the fence type(s) identified in the pilot study as having the greatest potential for containing feral swine, and subsequently, 3) determine the efficacy of the selected fence type(s) to contain feral swine under increasing levels of motivation.

\section{STUDY AREA}

We conducted our evaluation during summer 2009 at Texas A\&M University-Kingsville (TAMUK) Captive Wildlife Research Facility, located $5 \mathrm{~km}$ south of Kingsville in Kleberg County, Texas, USA $\left(27^{\circ} 28^{\prime} \mathrm{N}, 97^{\circ} 53^{\prime} \mathrm{W}\right)$. Mean maximum monthly temperatures from July through September were $36.4^{\circ} \mathrm{C}$ (National Climatic Data Center, $<$ http://www.ncdc.noaa.gov $>$ ). Topography was flat and the area contained native vegetation including honey mesquite (Prosopis glandulosa), spiny hackberry (Celtis pallida), and lime pricklyash (Zanthoxylum fagara) with minimal ground cover.

\section{METHODS}

\section{Study Animals}

We captured free-ranging feral swine using box traps or purchased swine from local trappers who trapped them for our study. We captured feral swine in Refugio, Kleberg, and Kenedy counties, Texas. We recorded gender, weight, age, color, and status (died, escaped, or contained) for each study animal. We recorded carcass weights after euthanizing animals. We categorized feral swine as juveniles $(<30 \mathrm{~kg})$ or adults $(\geq 30 \mathrm{~kg}$; Hone and Atkinson 1983, Fernández-Llario and Mateos-Quesada 1998, Sparklin et al. 2009).

We housed feral swine prior to trials in $89-\mathrm{m}^{2}$ pens with free access to shade, water, and food (whole-kernel corn and a custom swine maintenance diet; USDA Pig, Lyssy and Eckels, Poth, TX). We marked individual feral swine with numbered eartags (Allflex ${ }^{\circledR}$, Dallas Fort Worth Airport, TX) so we could determine if any trends emerged based on age, gender, and size of animals that escaped experimental enclosures. We conducted our study behind a 2.4-m-tall wire mesh perimeter fence to ensure that no swine would escape to the wild. Thus all of the feral swine that escaped test fences during our study were still confined and euthanized as soon as possible. The Institutional Animal Care and Use Committee at TAMUK (2009-06-17B) reviewed and approved all procedures. 


\section{Fence Type Pilot Study}

To support our final selection of fence type for our experiment, we conducted a pilot study of 5 fence types. We conducted a single trial, each involving 5 animals within each fence type. The 5 types of fence materials we evaluated included: 1) electrified polywire (polywire), 2) electrified netting, 3) polypropylene mesh (polypro mesh), 4) hog panels, and 5) woven-wire mesh.

We modeled the polywire enclosure after a design that was most effective in excluding feral swine in previous research at this facility (Reidy et al. 2008). We used 1.2-m-tall step-in electric fence posts (Fi-Shock ${ }^{\mathrm{TM}}$, Lititz, PA) and 3 strands of Speedrite ${ }^{\mathrm{TM}}$ polywire (Tru-Test ${ }^{\mathbb{R}}$ Mineral Wells, TX) spaced at $0.20 \mathrm{~m}, 0.45 \mathrm{~m}$, and $0.71 \mathrm{~m}$ above ground. The polywire was approximately $3 \mathrm{~mm}$ in diameter and consisted of white ultraviolet-stabilized polyethylene twine braided with tin-plated copper wire. All strands of fence were electrified with a 12-V Speedrite 3000 energizer (Tru-Test) with a verified voltage of 10 kilovolts $(\mathrm{kV})$ using a digital voltmeter (IntelliTest ${ }^{\mathrm{TM}}$ Digital Voltmeter, Premiere 1, Washington, IA). Energizers were powered with $12-\mathrm{V}$ deep-cycle marine batteries.

We used Kencove 14/48/3.5 electric netting (Kencove Farm Fence Inc., Blairsville, PA) with built-in plastic posts for the second enclosure. Netting consisted of orange polyethylene twine braided with stainless-steel wire. Vertical strands were $8.9 \mathrm{~cm}$ apart and horizontal strands were spaced as follows: lowest 7 strands were $6.4 \mathrm{~cm}$ apart, next 6 strands $10.2 \mathrm{~cm}$ apart, and top 2 strands were $22.9 \mathrm{~cm}$ apart, which resulted in an overall fence height of $1.2 \mathrm{~m}$. The bottom strand was non-conductive, thus would not short if contacting wet vegetation. We provided additional support for the fence with step-in plastic posts, with built-in clips, installed every $1.7 \mathrm{~m}$ between built-in posts. We electrified the fence with a $12-V$ Speedrite 3000 energizer that provided a verified voltage of $9 \mathrm{kV}$.

We used $1.5-\mathrm{m}$-tall heavy-duty polypro deer netting $(5-\mathrm{cm}$ squares; Benner's Garden, Phoenixville, PA) with an inwardfacing $0.5-\mathrm{m}$ apron for the third enclosure. We constructed the fence using 2-m-tall steel t-posts (e.g., GWP Industries Co., LTD., Tianjin, China) spaced every $2.4 \mathrm{~m}$ and driven $0.5 \mathrm{~m}$ into the ground. We used 11-gauge (ga) nylon monofilament line (Benner's Garden) positioned at $0.2 \mathrm{~m}$ and $1 \mathrm{~m}$ above the ground to add support to the polypro mesh. We attached mesh to the monofilament every $0.60 \mathrm{~m}$ using a Stanley ${ }^{\mathbb{B}}$ Hogringer (Stanley, Britain, CT) and to t-posts at $0.0 \mathrm{~m}, 0.5 \mathrm{~m}$, and $1 \mathrm{~m}$ using heavy-duty zip ties (Benner's Garden). We used 0.25-m-long, 0.79-cm-diameter, galvanized-steel stakes (Benner's Garden) to secure mesh to the ground every $2.4 \mathrm{~m}$.

We used traditional 4.8-m-long $\times$ 0.86- $\mathrm{m}$-tall hog panels (Oklahoma Steel and Wire Company Inc. Madill, OK) constructed of 4-ga welded wire for the fourth enclosure. Vertical stays were spaced $20.3 \mathrm{~cm}$ apart. Horizontal wires were spaced from the ground up with 4 5.1-cm gaps, 2 7.6cm gaps, $110.2-\mathrm{cm}$ gap, $212.7-\mathrm{cm}$ gaps, and $115.2-\mathrm{cm}$ gap. We used 2-m-tall steel t-posts spaced every $2.4 \mathrm{~m}$ and driven $0.50 \mathrm{~m}$ into the ground to support the fence. We attached hog panels to t-posts with 17 -ga wire at $0.05 \mathrm{~m}, 0.15 \mathrm{~m}$, $0.25 \mathrm{~m}, 0.5 \mathrm{~m}$, and $0.80 \mathrm{~m}$ above ground.

We installed 1.24-m-tall high-tensile, woven-wire mesh (949-6, Stay-Tuff ${ }^{\mathrm{R}}$, New Braunfels, TX) for the fifth enclosure. The fence had vertical stays every $15.2 \mathrm{~cm}$ and spacing of horizontal wires with 212.7 -cm gaps, $315.2-\mathrm{cm}$ gaps, and $317.8-\mathrm{cm}$ gaps from the ground up. We constructed hbraces at the corners using $2.34-\mathrm{m}$-tall $\times 0.15$-m-diameter, treated wooden posts with horizontal braces of $6.4-\mathrm{cm}^{-}$ diameter, schedule- 40 steel pipe. We placed posts $2.4 \mathrm{~m}$ apart and $1.1 \mathrm{~m}$ in the ground. We installed $2-\mathrm{m}$ steel tposts every $4.8 \mathrm{~m}$ and $0.50 \mathrm{~m}$ into the ground to support the runs. We attached fence to $\mathrm{t}$-posts using $\mathrm{t}$-post clips located at $0.15 \mathrm{~m}, 0.60 \mathrm{~m}$, and $1.05 \mathrm{~m}$ above ground.

We recorded information pertaining to cost and time required to construct each 0.09 -ha enclosure. We rounded 2 corners (diagonally opposing) of each enclosure by creating a $10-\mathrm{m}$ arc with the fence material and recorded where escapes occurred to evaluate efficacy of rounded versus square corners. For each trial, we introduced 5 feral swine into an enclosure, which were immediately pursued by 3 people on foot with paintball projectors (Tippman ${ }^{\mathbb{B}} 98$ Custom, Tippman Sports LLC, Fort Wayne, IN) loaded with 30 oil-based light blue paintballs (Oil-Based Marking Pellets, Nelson Paint Company, Kingsford, MI) for 15 min or until all feral swine escaped the enclosure. We fired paintballs to push feral swine from cover. If an escape from an enclosure occurred, we deemed that fence type a failure.

\section{Experimental Containment Trials}

Our pilot study indicated the hog panel fence performed best. We subsequently constructed $250-\mathrm{m} \times 75-\mathrm{m}(0.38-$ ha) hog-panel enclosures; each with a $0.9-\mathrm{m} \times 0.9-\mathrm{m}$ gate to facilitate transferring feral swine from trailer to enclosure at the beginning of each trial. Overall construction was similar to the pilot study; however, we rounded all 4 corners of each enclosure. We cleared and raked a $1.5-\mathrm{m}$-wide strip of soil immediately outside each enclosure (track perimeter) to create substrate where tracks would be easily identified if hogs escaped. During trials, we checked track perimeters twice daily so we could determine how and where escapes occurred.

We conducted 30 successive trials and 5 independent trials to evaluate efficacy of the hog-panel fence under various levels of human pursuit. We ran trials simultaneously, though temporally staggered, for the duration of the study (Fig. 1). Trials began with a 3-day relaxed phase ( $\mathrm{R}$ phase). The $R$ phase began the morning of day 1 with introduction of 6 randomly selected feral swine. Days $1-3$, we inventoried feral swine every morning and evening when we fed and watered them and checked track perimeters. If an escape occurred during the $\mathrm{R}$ phase we immediately replaced the individual to ensure 6 were present for subsequent phases.

At approximately sunrise of day 4 for all successive trials, we transitioned into the paintball-induced phase (PB phase). The $\mathrm{PB}$ phase involved 3 persons on foot with sorting panels $(0.76-\mathrm{m} \times 0.91-\mathrm{m})$ constructed of $1.6-\mathrm{cm}$-thick plywood and paintball projectors (loaded as described previously for 


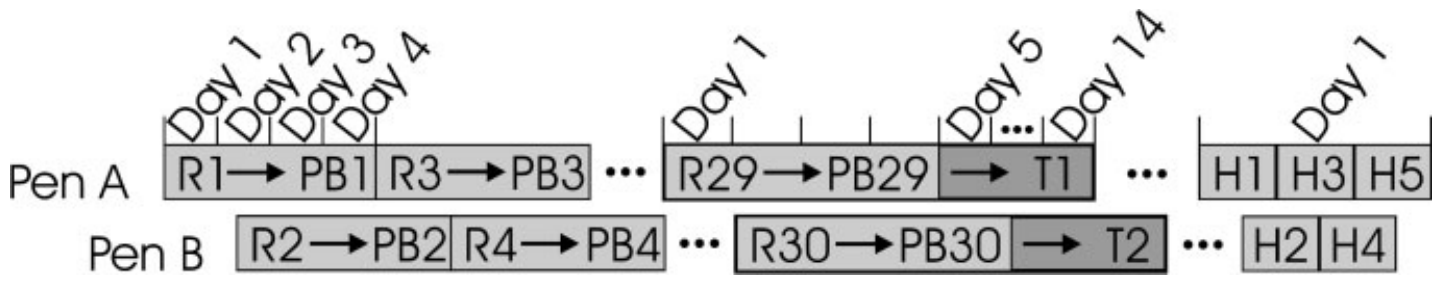

Figure 1. Chronological progression of trials within 2 enclosures constructed of 0.8 -m-tall hog panels to contain recently caught wild feral swine in Kingsville, Texas, USA, July-September 2009. R indicates relaxed phases in which were provided no additional stimuli to escape; PB indicates paintball phases in which personnel with paintball projectors pursued and marked feral swine; T indicates time-induced phases in which feral swine were allowed to remain in enclosures an additional 10 days beyond $\mathrm{PB}$ phases; and $\mathrm{H}$ indicates independent helicopter trials in which we systematically removed and motivated feral swine by aerial gunning.

pilot study). Personnel were positioned evenly along the short axis of the enclosure and made 10 lengthwise passes through the enclosure. The first 2 passes involved stalking with an emphasis on shot placement and a goal of marking all feral swine as efficiently as possible. The remaining 8 passes involved a raucous drive to further motivate feral swine to escape. We recorded time lapsed to mark all individual feral swine, simulating a lethal removal of the entire group, had firearms been used instead of paintball projectors. We recorded details on escapes including individual, location, time, and means of escaping (e.g., over, under, or through the fence).

For the last 2 trials, we acquired additional containment data by proceeding into a time-induced phase ( $\mathrm{T}$ phase) following $\mathrm{PB}$ phases. Each $\mathrm{T}$ phase involved further containment of 6 feral swine for 14 days (10 additional days beyond the $\mathrm{PB}$ phase). As before, we provided ad libitum fresh water, whole-kernel corn, and pelletized feed. We walked enclosure perimeters once daily to document escapes. After PB and T phases, we euthanized feral swine by firearm (Longair et al. 1991, American Veterinary Medical Association 2007).

Lastly, we conducted 5 independent trials involving helicopter-induced motivation ( $\mathrm{H}$ trials) including systematic removal by aerial gunning. We also conducted helicopter trials with 6 feral swine per trial. We introduced each group of feral swine to enclosures and motivated them to escape within $24 \mathrm{hr}$. The helicopter hovered over enclosures to force feral swine to leave cover (requiring 1-9 min). Once feral swine were exposed and running, the gunner removed animals at a rate of 1 animal per $30 \mathrm{sec}$. A controlled removal rate ensured that feral swine had an opportunity to escape the fence before being dispatched. We recorded total time for removals, duration of trials, and identification of any feral swine that escaped enclosures.

We estimated probability of containment $(\hat{p})$ for $\mathrm{R}$ and $\mathrm{PB}$ phases and for $\mathrm{H}$ trials. Although we used multiple animals per trial to simulate realistic conditions, we could not assume independence among individuals in groups, thus our units of analysis were groups of feral swine within each phase $\times$ trial combination for 2-phase trials ( $n=30$; $\mathrm{R}$ and $\mathrm{PB}$ phases) and groups within each helicopter trial $(n=5)$. We defined a binary response variable (status) for each unit of analysis, where status $=1$ when no feral swine per group escaped or status $=0$ when $\geq 1$ feral swine per group escaped. We estimated $\hat{p}$ and $95 \%$ confidence intervals in independent analyses for $\mathrm{R}$ and $\mathrm{PB}$ phases using methodology based on exact permutation distributions (Stokes et al. 2000) because swine groups occasionally differed from $\mathrm{R}$ and $\mathrm{PB}$ phases within trials when an escape occurred and $\hat{p}$ values were at or near parameter boundaries. We used exact logistic regression (Cox 1970, Derr 2000) to evaluate effect of pen (A and B) and to estimate $\hat{p}$ when $0<\hat{p}<1$ (PROC LOGISTIC; SAS Institute, Cary, $\mathrm{NC}$ ) where $\mathrm{CI}_{\text {mid- } P}$ was adjusted based on the mid- $P$-value to improve confidence interval coverage (Vollset et al. 1991, Brown et al. 2001, Agresti 2002). When $\hat{p}=1$, we used unadjusted exact methods in SAS PROC FREQ to estimate $\mathrm{CI}_{\text {exact }}$ (Clopper and Pearson 1934, Leemis and Trivedi 1996).

\section{RESULTS}

We conducted our pilot study of the 5 fence types from 6 July to 7 July 2009. All fence types except hog-panels failed to meet our criteria because feral swine escaped the enclosures. Feral swine within polywire were contained for $<5 \mathrm{sec}$. Electrified net contained feral swine for several minutes, but individuals eventually passed through or went under the fence during the trial. The polypro mesh contained feral swine for approximately $15 \mathrm{sec}$ until an adult male slashed a hole in the fence, through which all feral swine escaped. The woven-wire mesh fence contained 2 adult feral swine for the duration of the trial $(15 \mathrm{~min})$, though 2 juveniles $(<23 \mathrm{~kg}$ ) went under the fence and one squeezed through the lowest mesh $(15.2 \mathrm{~cm} \times 12.7 \mathrm{~cm})$ within 2 min of introduction. Hog panels did not allow any feral swine to escape during our pilot study and the incorporation of rounded corners into the design appeared to mitigate animals congregating in corners and potentially escaping by climbing onto each others' backs.

Costs to construct enclosures for the pilot study ranged from $\$ 2.62 / \mathrm{m}$ for polywire to $\$ 7.75 / \mathrm{m}$ for woven-wire (Table 1). Time to construct $30-\mathrm{m} \times 30-\mathrm{m}$ enclosures ranged from 3-60 person hours (no. people $\times$ no. hr). Both cost and time requirements were greatest for wovenwire, primarily due to construction of corners and h-braces necessary for tensioning fences.

We conducted our experimental trials between 9 July 2009 and 28 September 2009. Overall, our sample of feral swine $(n=214)$ consisted of $42 \%(n=90)$ juveniles and $50 \%$ ( $n=108)$ females; $29 \%$ of swine $(n=63)$ were $<23 \mathrm{~kg}$, $48 \%(n=102)$ were $23-45 \mathrm{~kg}$, and $23 \%(n=49)$ were $>45 \mathrm{~kg}$. Mean feral swine weight was $34.0 \mathrm{~kg}(\mathrm{SD}=17.8)$. From 30 successive trials and 5 helicopter trials, only 7 
Table 1. Costs of candidate fences in preliminary selection of containment fence for controlling disease outbreaks in feral swine in Kingsville, Texas, USA, JulySeptember 2009.

\begin{tabular}{lcccc}
\hline Fence & Cost $_{\text {per }}$ meter $\left.\mathbf{( \$ )}\right)^{\mathbf{a}}$ & Cost $^{\text {per corner } \mathbf{( \$ )}} \mathbf{b}^{\mathbf{b}}$ & Fence cost (\$) $^{\mathbf{c}}$ & Time to build (hr) $^{\mathbf{d}}$ \\
\hline Electrified polywire & 2.62 & 2.39 & 314.76 & 3 \\
Electrified netting & 6.20 & 0.00 & 744.40 & 5 \\
Polypropylene mesh & 5.74 & 11.67 & 688.68 & 15 \\
Hog panels & 5.73 & 3.89 & 687.56 & 20 \\
Woven wire & 7.75 & 151.25 & 930.20 & 60 \\
\hline
\end{tabular}

${ }^{a}$ Includes cost of materials with 4 corners.

${ }^{\mathrm{b}}$ Additional cost for corners.

${ }^{\mathrm{c}}$ Total cost of materials including corners, energizer, and $12-\mathrm{V}$ deep-cycle marine battery, but excluding labor.

${ }^{\mathrm{d}}$ Time required to build the fence does not include removal of vegetation.

failures occurred (Table 2). Throughout the study, 4 feral swine died of natural causes, 7 escaped test enclosures by jumping over, and 203 were contained by hog panels for the duration of their trials. The 7 feral swine that escaped hog-panel fences weighed an average $48.4 \mathrm{~kg}(\mathrm{SD}=14.4)$; 5 were males, and all were adults. All feral swine observed escaping (6 of 7 escapes) acted individually with no attempted escapes by accompanying feral swine. Of the 7 escapes that occurred, 4 were from pen $\mathrm{A}$ and 3 from pen $\mathrm{B}$. We observed one escape each in the $R$ and $T$ phases (pen $A$ ). During the PB phase, 2 escapes occurred in pen $\mathrm{A}$ and 3 in pen $\mathrm{B}$, providing little evidence of a pen effect (logistic regression pen effect: $\left.\beta=0.235 ; \mathrm{CI}_{\text {mid }-P}:-0.79,1.37\right)$.

We conducted 30 3-day $\mathrm{R}$ phases in which we estimated hog-panel fences to be $96.7 \%$ effective (95\% $\mathrm{CI}_{\text {mid- } P \text { : }}$ 0.846, 0.998 ) in containing feral swine under low levels of motivation (Table 2). We documented one escape by an adult male that fled and jumped over the fence on the second evening of a trial as a biologist entered the enclosure to fill a water tub.

We estimated that hog-panel fences were $83.3 \%$ effective $\left(\mathrm{CI}_{\text {mid- } P}: 0.669,0.936\right)$ during $\mathrm{PB}$ phases (Table 2$)$. Three adult males and 2 adult females escaped fences while being pursued. One escaped on the first pass through the enclosure and the other 4 escaped during the second pass. It took an average of $3.8 \mathrm{~min}(\mathrm{SD}=2.1)$ to mark all of the feral swine during $\mathrm{PB}$ trials and only 1 of 5 feral swine that escaped during $\mathrm{PB}$ phases was not marked prior to doing so.

We carried 2 groups of feral swine from $\mathrm{PB}$ phases into $\mathrm{T}$ phases, during which feral swine remained within their hog- panel enclosures for an additional 10 days. During $\mathrm{T}$ phases, enclosures were technically $50 \%$ successful in containing groups of feral swine; yet, only 1 of 12 feral swine escaped. Average weight for the 12 feral swine in $\mathrm{T}$ phases was $40.2 \mathrm{~kg}(\mathrm{SD}=17.4)$. We did not witness the escape by a small adult male (36 kg), which we simply found outside the test enclosure on day 13 of the trial.

For the $5 \mathrm{H}$ trials, we estimated hog-panel fences constructed of hog panels were $100 \%$ effective $\left(\mathrm{CI}_{\text {exact }}: 0.48\right.$, 1.00) under motivation by aerial gunning from a helicopter (Table 2). Average weight of 30 feral swine in $\mathrm{H}$ trials was $40.8 \mathrm{~kg}(\mathrm{SD}=21.6)$, of which $37 \%$ (11 of 30) were juveniles and 63\% (19 of 30) were females. The $\mathrm{H}$ trials lasted an average of $11.3 \mathrm{~min}(\mathrm{SD}=3.7)$ with average shooting duration of $6.0 \mathrm{~min}(\mathrm{SD}=2.4)$.

The only escape ( 1 of 7$)$ that took place within a rounded corner occurred on the second pass of a PB phase. We recorded no attempts by feral swine to escape the hog panels by rooting under or going through the fence.

\section{DISCUSSION}

We assumed that if a fence type evaluated in the pilot study failed to contain feral swine during a short-duration trial with moderate levels of motivation, it would also fail under elevated levels of motivation. As such, all except the metalmesh fences lacked potential for containment of pursued feral swine; however, these designs may sufficiently exclude feral swine under lower levels of motivation. The woven-wire

Table 2. Results from trials within 2 enclosures constructed of 0.8-m-high hog panels to contain recently caught wild feral swine in Kingsville, Texas, USA, July-September 2009.

\begin{tabular}{|c|c|c|c|c|c|}
\hline \multirow[b]{2}{*}{ Phase $^{\text {a }}$ or trial } & \multirow[b]{2}{*}{ No. trials ${ }^{b}$} & \multirow[b]{2}{*}{ Failed trials ${ }^{c}$} & \multirow[b]{2}{*}{ Total individuals that escaped } & \multicolumn{2}{|c|}{ Estimated probability of containmen } \\
\hline & & & & $\hat{p}$ & $95 \% \mathrm{CI}$ \\
\hline Relaxed & 30 & 1 & 1 & 0.97 & $0.85-1.00$ \\
\hline Paintball & 30 & 5 & 5 & 0.83 & $0.67-0.94$ \\
\hline Time & 2 & 1 & 1 & & \\
\hline Helicopter & 5 & 0 & 0 & 1.0 & $0.5-1.0$ \\
\hline
\end{tabular}

\footnotetext{
${ }^{a}$ Relaxed, Paintball, and Time indicate non-independent phases within successive trials in which the same animals were retained throughout. Relaxed indicated the initial 4 days of successive phases during which only routine animal care and fenceline inspections occurred. Paintball phases occurred at the conclusion of the Relaxed phase and involved a period of approx. 20-min pursuit by 3 biologists using paintball projectors and standardized procedures to mark swine and simulated lethal removal by ground crews. Time indicated a temporally extended phase of the last trial in each pen (10 days) and began immediately after the Paintball phase. Helicopter represents 5 independent trials in which we treated feral swine using lethal removal by shooting from a helicopter.

${ }^{\mathrm{b}}$ Each trial involved introducing 6 feral swine of mixed sex, size, and age to either pen A or B ( 0.38 ha, each).

${ }^{\mathrm{c}}$ Trials were classified as failures if $\geq 1$ individual animals escaped.
} 
mesh fence showed increased potential by containing 2 of 5 feral swine for the duration of the trial, although all escaped within $10 \mathrm{hr}$. Woven-wire mesh is available in a variety of mesh-size configurations and heights, thus potential for escapes over or through woven-wire mesh may be minimized by installing fences of different configuration (i.e., tighter spacing and increased height; Tilley 1973, Littauer 1993). Escape potential could be further minimized by eliminating the gap beneath the fence or by adding a strand of barbed wire at ground level (Tilley 1973).

We observed no incidences of feral swine attempting to jump over or escape under the 0.86-m hog-panel fences during our pilot study, thus we incorporated this design in our experiment. However, during experimental trials, we documented 7 of 214 feral swine that jumped over the 0.86 -m-tall fence. Only 2 of the 6 feral swine observed escaping the fence actually cleared the fence; the other 4 did not completely clear the fence and bent the top 1 or 2 horizontal wires. Based on these results and recommendations of others, we recommend that increasing fence height $(10-20 \mathrm{~cm})$ would mitigate such occurrences (Tilley 1973, Littauer 1993). In addition, only one of 7 escapes occurred within rounded corners. Rounded corners minimized congregation, as suggested in raceway designs for cattle by Grandin (2007), and also facilitated forward progress of feral swine along fence perimeters without considerable deceleration while being pursued (Warriss et al. 1992).

To mitigate the potential for disease outbreaks, selective or non-selective culling has reduced host populations to levels at which prevalence declines and transmission is minimized (Saunders and Bryant 1988, Carter et al. 2009). Previous studies have evaluated efficacy of such lethal control techniques for feral swine (Campbell and Long 2009) including aerial gunning (lethal removal from helicopter; Hone 1990, Saunders 1993, Dexter 1996, Campbell et al. 2010), snaring (Anderson and Stone 1993), hunting (Katahira et al. 1993, Sodeikat and Pohlmeyer 2002), toxicants (Choquenot et al. 1990), and trapping (Choquenot et al. 1993). Many lethal control methods heighten levels of motivation to escape; thus, given the mobility of feral swine, lethal population reduction activities have potential to disperse animals over wider areas (Saunders and Bryant 1988, Laddomada 2000, Sodeikat and Pohlmeyer 2002, Kramer-Schadt et al. 2007). The use of impermeable barriers to mitigate feral swine movements in response to culling or depopulation programs may be beneficial (Katahira et al. 1993).

With human pursuit being a primary factor motivating escape behavior, we expected $\mathrm{R}$ phases to involve the lowest level of motivation, thus the least potential for escapes from the hog-panel fences. However, 1 escape occurred during an $\mathrm{R}$ phase. As predicted, $\mathrm{PB}$ phases provided elevated motivation, as they were intended to simulate a lethal-removal drive. We conducted the first 2 stalking passes through the enclosure during $\mathrm{PB}$ phases with stealth and were predicted to be less disruptive than the following 8 passes. These presumably less disruptive initial passes, however, led to all 5 escapes documented during PB phases.
In a true lethal-removal drive, animals marked by paintballs would have been unavailable to escape. Thus, in our situation, 4 fewer feral swine (those marked prior to escaping) would have escaped during lethal-removal drives. At the conclusion of each trial, we remotely euthanized all feral swine using a non-suppressed, 0.308-caliber rifle from $<50 \mathrm{~m}$. Although this tactic was not a formal experimental treatment, it resulted in a consistently applied level of motivation under which no escapes occurred, suggesting it resulted in a lower level of motivation when compared to levels of successive trials.

We conducted $\mathrm{T}$ phases to bolster data regarding efficacy of hog-panel fences over time. Natural factors associated with social hierarchy may have played a role in motivating 1 feral swine to escape on day 13 of that phase. The individual was third largest of 4 males accompanying 2 females, suggesting he was displaced by larger males. Yet, 6 feral swine in a $0.38-$ ha enclosure is equivalent to 15 feral swine/ha, a density much lower than 67 feral swine/ha used in a previous evaluation of fences for feral swine (Hone and Atkinson 1983). Our results differed from Hone and Atkinson (1983) in that feral swine escaped their test enclosures soon after being contained, where we documented only 1 individual escaping prior to day 4 of our evaluations.

We expected aerial gunning in $\mathrm{H}$ trials to disperse feral swine and induce more escapes than other means; however, it was the only group of phases or trials in which we had no escapes. Additionally, it was occasionally difficult to even flush feral swine from cover with the helicopter, suggesting that dispersals induced by helicopter pursuit in similar settings may be minimal and that fences may be effective alone or in combination with natural barriers such as rivers to facilitate aerial gunning (Saunders and Bryant 1988, Campbell et al. 2010).

In the event of a disease outbreak requiring rapid response and containment of feral swine, ease of set-up and transport of fence materials are important factors that should be considered during fence selection, as expansive areas requiring large quantities of fence would be likely (Saunders and Bryant 1988). For example, to enclose $1 \mathrm{~km}^{2}$ would require $4,000 \mathrm{~m}$ of fence (820 hog panels). Estimated total cost to enclose $1 \mathrm{~km}^{2}$ with hog-panel fence is $\$ 26,250$ (including labor at $\$ 10 / \mathrm{hr}$ ) and would require about 48 -hr days to construct with a crew of 10 people. Enclosures of larger-scale would result in a larger area-to-fence line ratio than in this study, thus decreasing the occurrence of animals encountering fences and potential for escapes. We considered ease of set-up (i.e., measure of time, difficulty, and tools required) among all of our candidate fences and those of lower efficacy (i.e., polywire and electrified netting) were quickest ( $3 \mathrm{hr}$ and $5 \mathrm{hr}$, respectively; Table 1 ) and easiest (i.e., no digging or use of heavy equipment) to erect. Woven-wire mesh fence was quick to erect once h-braces were constructed; however, hbraces required considerable time for planning, digging holes, and construction. Additionally, fence stretchers or a vehicle were needed to tension the fence. Further, additional in-line $\mathrm{h}$-braces or rigid posts are required whenever a fenceline deviates in direction (vertical or horizontal), increasing time and cost of construction. 
Construction requirements for hog-panel fences were minimal, with no digging, little planning, and no need for specialized equipment. Bolt cutters, a hand-held t-post pounder, and fencing pliers were all the tools required for construction. Availability of hog-panels and these basic fencing tools is widespread. The design of hog-panel fence construction lends well to fence runs with vertical and horizontal irregularities that may be encountered if pre-existing corridors such as road rights-of-way are not used. Panels can be trimmed easily or small trenches can be dug with hand tools and additional pieces of fence can be secured beneath panels to ensure that contours of the ground are followed closely. Hog-panel fences require no tension and one panel is essentially independent of the next, thus fences constructed of hog panels can change direction abruptly without requiring additional bracing or compromising integrity of adjacent sections.

The only apparent weakness of our selected hog panels was height. Fortunately, hog panels are available in greater heights $(1.3-1.5 \mathrm{~m})$ at an additional cost of $\$ 10-\$ 15$ per panel. The spacing of horizontal and vertical stays is designed specifically for all sizes of domestic swine. We considered using taller panels and burying the lower edge in the ground to discourage rooting under. In the end, we chose to do what would be quickest and least labor intensive (with extensive enclosures and rapid response in mind) and to use a product that is widely available. Had we selected $1.3-\mathrm{m}$-tall hog panels, success in containment likely would have been $100 \%$, although use of taller panels would not have furthered the understanding of how high the most capable feral swine are able to jump.

In a disease outbreak, fences may be used in a variety of ways, including containment and facilitating driving feral swine into a specific area to be caught or shot. Fences would minimize immigration into a disease-outbreak area, improving chances for a complete depopulation and disease control in a closed population. Provision of food and water in a non-disruptive environment may minimize dispersals during response to a disease outbreak (Laddomada 2000, Geisser and Reyer 2004). Thoughtful placement of enclosures to encompass existing resources may further diminish desire and potential for dispersal. Provision of preferred foods and water in conjunction with fencing may facilitate depopulation and further minimize spread of disease in an outbreak situation.

\section{MANAGEMENT IMPLICATIONS}

Our objectives were directed at disease containment; however, hog-panel fences could be suitable in a variety of applications by state and federal agencies, private landowners, and livestock producers impacted by feral swine. The levels of motivation in which feral swine were subjected to in our evaluation likely were much higher than would be experienced in agricultural settings, thus hog-panel fences would likely be more effective in protecting fruits, vegetables, agricultural crops, and livestock from feral swine. Hog-panel fences are designed for and commonly used in containment of domestic swine but have utility in other applications, especially where costs associated with risks are high. The fence design we tested could be useful in protecting valuable resources such as vegetable crops. For agricultural applications a benefit-cost analysis should be conducted to determine economics associated with reduced crop damaged relative to fence cost (VerCauteren et al. 2006b).

Specific depopulation strategies (e.g., aerial gunning, sharpshooting, etc.) and potential associated levels of motivation to escape fences must be considered during selection of fence materials and design for disease control, particularly when human pursuit is involved. Our documented lack of escapes suggests aerial gunning and sharpshooting may not compromise efficacy of the 0.86 -m-tall hog-panel fence we tested. Although we documented promising results with the fence tested, we recommend using panels of greater height $(1.3 \mathrm{~m})$ in situations with potential for catastrophic results if escapes occur. Additionally, if used as a biosecurity measure to reduce risk of disease transmission at the interface between domestic livestock and free-ranging feral swine, additional strategies (i.e., double fencing) may be necessary to eliminate potential for direct interaction. Characteristics of hog-panel fences such as ease of construction, moderate cost $(\$ 5.73 / \mathrm{m})$, and widespread availability lends well to temporary usage and immediacy, such as would be experienced during a disease response situation, but also broadens utility of hog-panel fences from disease control to damage management.

\section{ACKNOWLEDGMENTS}

We thank D. Baasch, C. Betsil, Z. Bowers, C. Brock, G. Clements, J. Cumbee, A. Hildreth, T. Hutton, K. Lawry, B. Leland, T. Musante, K. Pedersen, J. Ratton, T. Ruby, R. Sinclair, B. Sparklin, and T. Taylor for assistance. We thank the Caesar Kleberg Wildlife Research Institute at Texas A\&M University-Kingsville and Texas Wildlife Services for logistic support. We are grateful to the United States Department of Agriculture (USDA), Animal and Plant Health Inspection Service, Wildlife Services, National Wildlife Disease Program for financial support. Mention of companies or commercial products does not imply recommendation or endorsement by the USDA nor does omission imply criticism. Product names are mentioned solely to report factually on available data and to provide specific information.

\section{LITERATURE CITED}

Agresti, A. 2002. Categorical data analysis. Second edition. John Wiley \& Sons, Hoboken, New Jersey, USA.

American Veterinary Medical Association. 2007. AVMA guidelines on euthanasia. <http://www.avma.org/resources/euthanasia.pdf $>$. Accessed 8 Feb 2011.

Anderson, S. J., and C. P. Stone. 1993. Snaring to control feral pigs Sus scrofa in a remote Hawaiian rain forest. Biological Conservation 63:195-201.

Artois, M., R. Delahay, V. Guberti, and C. Cheeseman. 2001. Control of infectious diseases of wildlife in Europe. The Veterinary Journal 162:141-152.

Artois, M., K. R. Depner, V. Guberti, J. Hars, S. Rossi, and D. Rutili. 2002. Classical swine fever (hog cholera) in wild boar in Europe. Revue Scientifique et Technique Office International des Epizooties 21:287303. 
Atwill, E. R., R. A. Sweitzer, M. C. Pereira, I. A. Gardner, D. Van Vuren, and W. M. Boyce. 1997. Prevalence of and associated risk factors for shedding Cryptosporidium parvum oocysts and Giardia cysts within feral pig populations in California. Applied and Environmental Microbiology 63:3946-3949.

Brown, L. D., T. T. Cai, and A. DasGupta. 2001. Interval estimation for a binomial proportion. Statistical Science 16:101-133.

Brugh, M., J. W. Foster, and F. A. Hayes. 1964. Studies on the comparative susceptibility of wild European and domestic swine to hog cholera. American Journal of Veterinary Research 25:1124-1127.

Campbell, T. A., and D. B. Long. 2009. Feral swine damage and damage management in forested ecosystems. Forest Ecology and Management 257:2319-2326.

Campbell, T. A., D. B. Long, and B. R. Leland. 2010. Feral swine behavior relative to aerial gunning in southern Texas. Journal of Wildlife Management 74:337-341.

Carter, S. P., S. S. Roy, D. P. Cowan, G. Massei, G. C. Smith, W. Ji, S. Rossi, R. Woodroffe, G. J. Wilson, and R. J. Delahay. 2009. Options for the control of disease 2: targeting hosts. Pages 121-146 in R. J. Delahay, G. C. Smith, and M. R. Hutchings, editors. Management of disease in wild mammals. Springer, Tokyo, Japan.

Choquenot, D., B. Kay, and B. Lukins. 1990. An evaluation of warfarin for the control of feral pigs. Journal of Wildlife Management 54:353-359.

Choquenot, D., R. J. Kilgour, and B. S. Lukins. 1993. An evaluation of feral pig trapping. Wildlife Research 20:15-22.

Clopper, C. J., and E. S. Pearson. 1934. The use of confidence or fiducial limits illustrated in the case of the binomial. Biometrika 26:404-413.

Cowled, B., and G. Garner. 2008. A review of geospatial and ecological factors affecting disease spread in wild pigs: considerations for models of foot-and-mouth disease spread. Preventive Veterinary Medicine 87:197-212.

Cox, D. R. 1970. The Analysis of Binary Data. Chapman \& Hall, New York, New York, USA.

Cushman, J. H., T. A. Tierney, and J. M. Hinds. 2004. Variable effects of feral pig disturbances on native and exotic plants in a California grassland. Ecological Applications 14:1746-1756.

Derr, R. E. 2000. Performing exact logistic regression with the SAS $^{\circledR}$ system. Proceedings of SAS ${ }^{\circledR}$ Users Group International Conference 25.

Dexter, N. 1996. The effect of an intensive shooting exercise from a helicopter on the behaviour of surviving feral pigs. Wildlife Research 23:435-441.

Ditchkoff, S. S., and B. C. West. 2007. Ecology and management of feral hogs. Human-Wildlife Conflicts 1:149-151.

Doupé, R. G., J. Mitchell, M. J. Knott, A. M. Davis, and A. J. Lymbery. 2009. Efficacy of exclusion fencing to protect ephemeral floodplain lagoon habitats from feral pigs (Sus scrofa). Wetlands Ecology and Management 18:69-78.

Dudley, J. P., and M. H. Woodford. 2002. Bioweapons, bioterrorism and biodiversity: potential affects of biological weapons attacks on agricultural and biological diversity. Revue Scientifique et Technique Office International des Epizooties 21:125-137.

Fernández-Llario, P., and P. Mateos-Quesada. 1998. Body size and reproductive parameters in the wild boar Sus scrofa. Acta Theriologica 43:439-444.

Geisser, H., and H. Reyer. 2004. Efficacy of hunting, feeding, and fencing to reduce crop damage by wild boars. Journal of Wildlife Management 68:939-946.

Grandin, T. 2007. Handling facilities and restraint of range cattle. Pages 90108 in T. Delahay, editor. Livestock handling and transport. Center for Agricultural Bioscience International, Cambridge, Massachusetts, USA.

Hone, J. 1990. Predator-prey theory and feral pig control, with emphasis on evaluation of shooting from a helicopter. Australian Wildlife Research 17:123-130.

Hone, J., and B. Atkinson 1983. Evaluation of fencing to control feral pig movement. Australian Wildlife Research 10:499-505.

Hone, J., and C. P. Stone 1989. A comparison and evaluation of feral pig management in two national parks. Wildlife Society Bulletin 17:419-425.

Jay, M. T., M. Cooley, D. Carychao, G. W. Wiscomb, R. A. Sweitzer, L. Crawford-Miksza, J. A. Farrar, D. K. Lau, J. O'Connell, A. Millington, R. V. Asmundson, E. R. Atwill, and R. E. Mandrell. 2007. Escherichia coli
O157:H7 in feral swine near spinach fields and cattle, central California coast. Emerging Infectious Diseases 13:1908-1911.

Katahira, L. K., P. Finnegan, and C. P. Stone. 1993. Eradicating feral pigs in montane mesic habitat at Hawaii Volcanoes National Park. Wildlife Society Bulletin 21:269-274.

Kramer-Schadt, S., N. Fernández, and H. H. Thulke. 2007. Potential ecological and epidemiological factors affecting the persistence of classical swine fever in wild boar Sus scrofa populations. Mammal Review 37:1-20.

Laddomada, A. 2000. Incidence and control of CSF in wild boar in Europe. Veterinary Microbiology 73:121-130.

Leemis, L. M., and K. S. Trivedi 1996. A comparison of approximate interval estimators for the Bernoulli parameter. American Statistician 50:63-68.

Littauer, G. A. 1993. Control techniques for feral hogs. Pages 139-148 in C. W. Hanselka and J. F. Cadenhead, editors. Feral swine: a compendium for resource managers. Texas Agricultural Extension Service, Kerrville, Texas, USA.

Longair, J. G., G. Finley, M. A. Laniel, C. MacKay, K. Mould, E. D. Olfert, H. Rowsell, and A. Preston. 1991. Guidelines for euthanasia of domestic animals by firearms. Canadian Veterinary Journal 32:724-726.

McCann, B. E., and D. K. Garcelon. 2008. Eradication of feral pigs from Pinnacles National Monument. Journal of Wildlife Management 72:1287-1295.

McVicar, J. W., C. A. Mebus, H. N. Becker, R. C. Belden, and E. P. Gibbs. 1981. Induced African swine fever virus in feral pigs. Journal of the American Veterinary Medical Association 179:441-446.

Meng, X. J., D. S. Lindsay, and N. Sriranganathan. 2009. Wild boars as sources for infectious diseases in livestock and humans. Philosophical Transactions of the Royal Society of Biological Sciences 364:2697-2707.

Paarlberg, P. L., A. Hillberg Seitzinger, H. G. Lee, and K. H. Mathews. 2009. Supply reductions, export restrictions, and expectations for hog returns in a potential classical swine fever outbreak in the United States. Journal of Swine Health and Production 17:155-162.

Pineda-Krch, M., J. M. O’Brien, C. Thunes, and T. E. Carpenter. 2010. Potential impact of introduction of foot-and-mouth disease from wild pigs into commercial livestock premises in California. American Journal of Veterinary Research 71:82-88.

Plant, J. W. 1980. Electric fences will give feral pigs a shock. Agricultural Gazette of New South Wales 91:38-40.

Richardson, C. D., P. S. Gipson, D. P. Jones, and J. C. Luchsinger. 1997. Extirpation of a recently established feral pig population in Kansas. Proceedings of Eastern Wildlife Damage Management Conference 7:100-103.

Reidy, M. M., T. A. Campbell, and D. G. Hewitt. 2008. Evaluation of electric fencing to inhibit feral pig movements. Journal of Wildlife Management 72:1012-1018.

Romero, C. H., P. N. Meade, J. E. Shultz, H. Y. Chung, E. P. Gibbs, E. C. Hahn, and G. Lollis. 2001. Venereal transmission of pseudorabies viruses indigenous to feral swine. Journal of Wildlife Diseases 37:289-296.

Rossi, S., E. Fromont, D. Pontier, C. Crucière, J. Hars, J. Barrat, X. Pacholek, and M. Artois. 2005. Incidence and persistence of classical swine fever in free-ranging wild boar (Sus scrofa). Epidemiology and Infection 133:559-568

Saunders, G., and H. Bryant. 1988. The evaluation of a feral pig eradication program during a simulated exotic disease outbreak. Australian Wildlife Research 15:73-81.

Saunders, G. 1993. Observations on the effectiveness of shooting feral pigs from helicopters. Wildlife Research 20:771-776.

Seward, N. W., K. C. VerCauteren, G. W. Witmer, and R. M. Engeman. 2004. Feral swine impacts on agriculture and the environment. Sheep and Goat Research Journal 19:24-40.

Sodeikat, G., and H. K. Pohlmeyer. 2002. Temporary home range modifications of wild boar family groups (Sus scrofa L.) caused by drive hunts in Lower Saxony (Germany). Zeitschrift für Jagdwissenschaft 48:161-166. Sodeikat, G., and K. Pohlmeyer. 2003. Escape movements of family groups of wild boar Sus scrofa influenced by drive hunts in Lower Saxony, Germany. Wildlife Biology 9:257-263.

Sparklin, B. D., M. S. Mitchell, L. B. Hanson, D. B. Jolley, and S. S. Ditchkoff. 2009. Territoriality of feral pigs in a highly persecuted population on Fort Benning, Georgia. Journal of Wildlife Management $73: 497-502$ 
Stokes, M. E., C. S. Davis, and G. G. Koch. 2000. Categorical data analysis using the SAS ${ }^{\circledR}$ system. SAS Institute, Cary, North Carolina, USA.

Swafford, S. R., B. B. Schmit, K. Pedersen, M. W. Lutman, and T. J. DeLiberto. 2009. Classical swine fever surveillance in feral swine. Proceedings of the Wildlife Damage Management Conference 13:1-5.

Thompson, D., P. Muriel, D. Russell, P. Osborne, A. Bromley, M. Rowland, S. Creigh-Tyte, and C. Brown. 2002. Economic costs of the foot-and-mouth disease outbreak in the United Kingdom in 2001. Revue Scientifique et Technique Office International des Epizooties 21:675-687.

Thomson, G. R., W. Vosloo, and A. D. S. Bastos. 2003. Foot and mouth disease in wildlife. Virus Research 91:145-161.

Tilley, L. G. W. 1973. Pig fencing in Mossman. Cane Growers Quarterly Bulletin 36:132-133.

United States Census Bureau. 2009. The 2009 statistical abstract. <http:// www.census.gov/compendia/statab/tables/09s0827.pdf $>$. Accessed 14 Dec 2009.

VerCauteren, K. C., M. J. Lavelle, and S. E. Hygnstrom. 2006a. Fences and deer-damage management: a review of designs and efficacy. Wildlife Society Bulletin 34:191-200.

VerCauteren, K. C., M. J. Lavelle, and S. E. Hygnstrom. 2006b. A simulation model for determining cost-effectiveness of fences for reducing deer damage. Wildlife Society Bulletin 34:16-22.

Vidrih, M., and S. Trdan. 2008. Evaluation of different designs of temporary electric fence systems for the protection of maize against wild boar (Sus scrofa L., Mammalia, Suidae). Acta Agriculturae Slovenica 91:343-349.
Vollset, S. E., K. F. Hirji, and A. A. Afifi. 1991. Evaluation of exact and asymptotic interval estimators in logistic analysis of matched case-control studies. Biometrics 47:1311-1325.

Ward, A. I., K. C. VerCauteren, W. D. Walter, E. Gilot-Fromont, S. Rossi, G. Edwards-Jones, M. Lambert, M. R. Hutchings, and R. J. Delahay. 2009a. Options for the control of disease 3: targeting the environment. Pages 147-168 in R. J. Delahay, G. C. Smith, and M. R. Hutchings, editors. Management of disease in wild mammals. Springer, Tokyo, Japan.

Ward, M. P., S. W. Laffan, and L. D. Highfield. 2009b. Modelling spread of foot-and-mouth disease in wild white-tailed deer and feral pig populations using a geographic-automata model and animal distributions. Preventive Veterinary Medicine 91:55-63.

Warriss, P. D., S. N. Brown, T. G. Knowles, and J. E. Edwards. 1992. Influence of width and bends on the ease of movement of pigs along races. Veterinary Record 130:202-204.

Wilcox, J. T., and D. H. Van Vuren. 2009. Wild pigs as predators in oak woodlands of California. Journal of Mammalogy 90:114-118.

World Organization for Animal Health (OIE). 2009. Foot and mouth disease. Chapter 8.5 in Terrestrial Animal Health Code. OIE home page. $<$ http://www.oie.int/eng/normes/mcode/en_chapitre_1.8.5. htm>. Accessed 15 Dec 2009.

Wyckoff, A. C., S. E. Henke, T. A. Campbell, D. G. Hewitt, and K. C. VerCauteren. 2009. Feral swine contact with domestic swine: a serologic survey and assessment of potential for disease transmission. Journal of Wildlife Diseases 45:422-429.

Associate Editor: Terry A. Messmer. 